\title{
Shrinkage behaviour and related corrosion performance of low-pH cementitious materials based on OPC or CAC
}

\author{
J.L. García-Calvo ${ }^{\mathrm{a} \bowtie}$, M. Sánchez ${ }^{\mathrm{a}}$, L. Fernández-Luco ${ }^{\mathrm{b}}$, M.C. Alonso ${ }^{\mathrm{a}}$ \\ a. Eduardo Torroja Institute for Construction Science, IETcc-CSIC (Madrid, Spain) \\ b. INTECIN-University of Buenos Aires (Buenos Aires, Argentina) \\ \jolgac@ietcc.csic.es
}

\author{
Received 27 march 2015 \\ Accepted 11 september 2015 \\ Available on line 04 february 2016
}

\begin{abstract}
Prior to using low-pH cementitious materials in underground repositories for high level waste, the characteristics determining their long-term durability must be analysed in depth. In this sense, different shrinkage tests have been made on mortar and concrete specimens using low-pH cement formulations based on ordinary portland cement (OPC) or calcium aluminate cement (CAC), with high mineral admixtures contents. They showed similar autogenous shrinkage than samples without mineral admixtures but higher drying shrinkage when materials based on OPC with high silica fume contents were considered. Besides, as the use of reinforced concrete could be required in underground repositories, the susceptibility of reinforcement to corrosion when using low-pH cementitious materials based on OPC was analyzed, considering carbon steel and galvanized steel. In the formers corrosion was detected due to the low pore solution $\mathrm{pH}$ but any problem was detected when galvanized reinforcement were used.
\end{abstract}

KEYWORDS: Radioactive wastes; Mixture proportion; Durability; Deformation; Corrosion

Citation/Citar como: García-Calvo, J.L.; Sánchez, M.; Fernández-Luco, L.; Alonso, M.C. (2016) Shrinkage behaviour and related corrosion performance of low-pH cementitious materials based on OPC or CAC. Mater. Construcc. 66 [321], e079. http://dx.doi.org/10.3989/mc.2016.02615.

RESUMEN: Fenómenos de retracción y comportamiento frente a la corrosión de materiales base cemento de bajo $\mathrm{pH}$ basados en $\mathrm{OPC}$ o $\mathrm{CAC}$. Previo al empleo de materiales con cementos de bajo $\mathrm{pH}$ en almacenamientos geológicos profundos (AGP) de residuos radiactivos de alta actividad, características relacionadas con su durabilidad a largo plazo deben ser verificadas. Así, su estabilidad volumétrica se ha analizado en morteros y hormigones de bajo $\mathrm{pH}$ basados en OPC o CAC, con elevados contenidos de adiciones minerales. Estos presentaron retracciones autógenas similares a las medidas en materiales convencionales, pero retracciones por secado mayores en los basados en OPC y altos contenidos de humo de sílice. Dado que en zonas de los AGP podría emplearse hormigón armado, también se evaluó la susceptibilidad a la corrosión de aceros al carbono y aceros galvanizados en materiales de bajo $\mathrm{pH}$ basados en OPC. Se detectó un inicio temprano de corrosión en los primeros debido al bajo $\mathrm{pH}$ presente en el fluido de los poros de estos materiales, sin detectarse problemas al emplear aceros galvanizados.

PALABRAS CLAVE: Residuos radioactivos; Proporción de mezcla; Durabilidad; Deformación; Corrosión

Copyright: (C) 2016 CSIC. This is an open-access article distributed under the terms of the Creative Commons Attribution-Non Commercial (by-nc) Spain 3.0 License. 


\section{INTRODUCTION}

Low $\mathrm{pH}$ cementitious materials have been considered to be used in underground repositories for high level waste (HLW), and their microstructural and mechanical properties as well as their resistance against groundwater aggression have been assessed (1-7). Their development has been addressed from different approaches depending on the type of base cement used. In this sense, the present paper is focused on low-pH cementitious materials based on ordinary portland cement (OPC) or calcium aluminate cement (CAC). In both cases, the use of high mineral admixtures contents is mandatory to achieve the required pore fluid $\mathrm{pH}$ and also to avoid the microstructural conversion process in the materials based on CAC $(3,6,7)$. These high mineral admixtures contents promote important changes in the microstructural parameters, e.g., in both cases, the resulting cementitious materials mainly consist of calcium silicoaluminate hydrates $(\mathrm{C}-\mathrm{A}-\mathrm{S}-\mathrm{H}$ matrixes) with low alumina content in those based on $\operatorname{OPC}(6,7)$. As expected, these microstructural changes also promote modifications in the resulting performance parameters (strength gain, final strength value, etc.) and in their durability properties, such as their resistance against ground water aggression (3-7).

However, regarding the durability parameters of these special materials, there are still some characteristics that must be analyzed in depth. For example, the high mineral admixtures contents used in the binder formulation are expected to promote important shrinkage processes. During its service life, concrete experiences volume changes independent from external loads, usually shrinkage, and it is well known that these volume changes due to shrinkage can lead to the cracking of the concrete and this would have detrimental effects in the HLW repository safety. In this sense, the inclusion of mineral admixtures in the concrete generally increases the water requirements for a concrete mixture, at least when high mineral admixtures contents $(>30 \%)$ are used, as in the present study. In theory, the increased water demand should increase the shrinkage of the concrete; however, some studies have shown that the use of mineral admixtures with an increased water demand does not always increase the shrinkage (8), at least in the very short-term (9).

In this study, the mineral admixtures used have been silica fume (SF) and class F low calcium fly ashes (FA). With respect to silica fume, Wiegrink et al. (10) found that high SF contents produced a concrete with higher early drying shrinkage but Tazawa and Yonekura (11) published opposite results. In fact, these differences can be related with the SF content used, as the addition of low $\mathrm{SF}$ contents $(5-10 \%)$ in concrete mixtures resulted in substantial reduction of drying shrinkage (12). Regarding FA, in the drying shrinkage tests conducted by Tangtermsirikul and Sudsangiam (13) in a controlled environment $\left(25^{\circ} \mathrm{C}\right.$ and $\left.60 \% \mathrm{RH}\right)$, cement pastes with the class $\mathrm{C}$ high calcium FA had a smaller drying shrinkage than the ordinary cement paste mixtures as the application of the FA reduced the water requirement of the mixtures. Moreover, recent studies have shown that replacing OPC partially by FA reduced drying shrinkage of concretes, even for similar water/binder ratios (14). On the contrary, other authors showed that, at $23{ }^{\circ} \mathrm{C}$ and $100 \% \mathrm{RH}$, concrete containing FA was not significantly different in shrinkage from the mixtures not containing FA (15). Therefore, inclusion of high FA contents promotes lower detrimental effects in shrinkage than the addition of high SF contents. In any case, the curing and the environmental conditions have significant effects on the rheological behavior of the concrete; for example, the drying shrinkage at early ages is quite dependent on the environmental conditions (16). In fact, Persson (17) found that the total shrinkage is related to the age, the w/c ratio and the SF content and, needless to say, this w/c ratio will vary depending on the material requirements (performance, execution techniques, etc.).

In addition, if the disposal of HLW in underground facilities required the use of concrete for structural support, thus implying the use of reinforced concrete, the steel reinforcement stability against corrosion could be compromised by the obtained low $\mathrm{pH}$ values in the concrete pore solutions. In previous paper, the susceptibility to corrosion when the carbon steel reinforcement is embedded in low-pH cementitious materials was analyzed (18). In that paper, a significant increase of the corrosion rate $\left(i_{\text {corr }}\right)$ values measured was detected when the pore fluid $\mathrm{pH}$ was lower than 11.5. After this moment, $i_{\text {corr }}$ values above the limit considered for passivation $\left(0.2 \mu \mathrm{A} / \mathrm{cm}^{2}\right)$ were maintained, indicating an active corrosion process. According to these results, alternative reinforcement or some additional protection measures against corrosion must be considered when low-pH cements are used in reinforced concretes for HLW repositories where long-term life is mandatory. In present paper, galvanized steel rebar were accordingly taken into account.

The main objective of this paper is to evaluate these durability parameters in low-pH cementitious materials defined to be used in specific applications for underground HLW repositories. These applications require the development of low-pH shotcreted concretes, as they are considered in many of the European HLW repository concepts already defined. In fact, the concretes evaluated in this paper have been already used in underground in-situ tests during the EU Project ESDRED (FI6W-CT2004-508851). 


\section{MATERIALS AND METHODS}

\subsection{Studies related to shrinkage measurements of low-pH cementitious materials}

The tests were conducted on mortar and concrete specimens, with equivalent consistency in each case, cured at different conditions in order to evaluate both the drying and the autogenous shrinkage. In the mortars, OPC type CEM I $42.5 \mathrm{R} / \mathrm{SR}$ and low calcium CAC were used as base cements, and $\mathrm{SF}$ and class F low calcium FA as mineral admixtures. The mortars were fabricated with a binder:siliceous sand ratio of 1:3 and the water/ binder $(w / b)$ ratios were determined for an equivalent consistency of $18 \pm 1 \mathrm{~cm}$ (measured according to UNE-EN 1015-3), adding 2\% in weight binder of superplasticizer (Naphthalene Formaldehyde base from Sika). As previously mentioned, many of the defined applications of low-pH concretes in HLW repositories will imply the use of the shotcreting technique. The development of a shotcreted concrete implies the previous development of a mortar (with the same binder) that has this consistency. The binder formulations used and the $\mathrm{w} / \mathrm{b}$ obtained in each case are shown in Table 1. It is remarkable the higher w/b ratio obtained in the low-pH formulations comparing to the ratios obtained in the corresponding references. This difference is higher in the case of B-1 formulation mainly due to its high SF content $(40 \%)$.

Mortar prisms $(25 \times 25 \times 287 \mathrm{~mm})$ were fabricated and both the autogenous and the drying skrinkage were measured according to UNE 80112-89 using a digital comparator. Two curing conditions were considered, evaluating two specimens of the same type in each condition:

- To evaluate the autogenous shrinkage two samples per binder formulation were wrapped in polyethylene, just after their removal from the moulds, to avoid any humidity exchange with the environment. They were maintained at $21 \pm 2{ }^{\circ} \mathrm{C}$ during 40-60 days when the volumetric changes were stabilized.

- To evaluate the drying shrinkage, the samples (two in each case) were cured at $98 \% \mathrm{RH}$ and $21 \pm 2{ }^{\circ} \mathrm{C}$

TABLE 1. Binder formulation and $w / b$ ratio of the fabricated mortars

\begin{tabular}{lcccc}
\hline & A-Ref & A-1 & B-Ref & B-1 \\
\hline OPC & - & - & 100 & 60 \\
CAC & 100 & 70 & - & - \\
SF & - & 20 & - & 40 \\
FA & - & 10 & - & - \\
w/b & 0.50 & 0.54 & 0.40 & 0.66 \\
\hline
\end{tabular}

temperature during 28 days and then they were cured at $50 \% \mathrm{RH}$ and $21 \pm 2{ }^{\circ} \mathrm{C}$ up to stabilization of the volumetric changes measurements.

The used low-pH concrete compositions were based on OPC plus SF (B-1 binder), as they were designed for the construction of a short shotcrete plug (B-1S) and a long shotcrete plug (B-1L) within the EU Project ESDRED (FI6W-CT-2004-508851), as plugs are required in HLW repositories in many places. A concrete mix based on OPC without mineral admixtures (B-Ref) with similar consistency was also used as reference. Table 2 shows the concrete mix compositions considered. The use of limestone filler and the absence of gravel in the B-1L concrete is due to the higher pumpability requirements of this concrete (a longer pumping distance) with respect to B-1S, also implying a slightly lower $\mathrm{w} / \mathrm{b}$ ratio in the former concrete comparing to the $\mathrm{w} / \mathrm{b}$ of the latter.

Concrete prisms $(76 \times 76 \times 286 \mathrm{~mm})$ were fabricated and both the autogenous and the drying shrinkage were measured according to ASTM C157 standard test using a digital comparator, evaluating two specimens of the same type in each condition. The same curing conditions considered in the mortars case were considered here.

\subsection{Studies related to the corrosion performance of carbon or galvanized steel reinforcement in low-pH mortars}

The B-1 binder, defined for the first time by authors (6), has been the commonly considered for HLW applications that have contemplated the use of reinforced concrete. On the contrary, the formulations based on CAC have been only defined for the construction of shotcrete plugs. For this reason, in this section only the formulations based on OPC are taken into account. Therefore, two different cement formulations were considered in the evaluated mortars: 100\% OPC (Ref) and 60\% OPC $+40 \%$ SF (B-1). A binder:siliceous sand ratio of 1:3 was used. The $\mathrm{w} / \mathrm{b}$ ratio was modified to obtain a similar fluidity (slump $=18 \pm 1 \mathrm{~cm})$ in both mortars $(\mathrm{w} / \mathrm{b}=0.4$ in Ref sample and $w / b=0.66$ in B-1 sample; $2 \% \mathrm{wt}$ binder of Naphthalene Formaldehyde base superplasticizer was added in both cases). Cylindrical samples of $50 \mathrm{~mm}$ in diameter with two embedded reinforcement (carbon steel or galvanized steel) were fabricated for both types of mortars. Steel reinforcement of $6 \mathrm{~mm}$ in diameter was used. The exposed area of the steel rebar was $5.65 \mathrm{~cm}^{2}$. To confirm the repeatability of the tests a total of four samples were used for each condition. The mortar samples were cured in a chamber at $98 \% \mathrm{RH}$ and $21 \pm 2{ }^{\circ} \mathrm{C}$ during the testing period. Electrochemical variables such as the corrosion potential $\left(\mathrm{E}_{\text {corr }}\right)$ and the polarization resistance $\left(R_{P}\right)$ were monitored from the fabrication 
TABLE 2. Nominal composition of the basic concretes fabricated

\begin{tabular}{lccc}
\hline & \multicolumn{3}{c}{ Binder formulations } \\
\cline { 2 - 4 } Components & B-Ref & B-1S & B-1L \\
\hline Binder formulation & $100 \%$ OPC & $60 \%$ OPC $+40 \% \mathrm{SF}$ & $60 \%$ OPC +40\% SF \\
Water $\left(\mathrm{kg} / \mathrm{m}^{3}\right)$ & 180 & 277 & 230 \\
Binder $\left(\mathrm{kg} / \mathrm{m}^{3}\right)$ & 300 & 307 & 275 \\
Water $/$ binder & 0.60 & 0.9 & 0.84 \\
Limestone Filler $\left(\mathrm{kg} / \mathrm{m}^{3}\right)$ & - & - & 70 \\
Gravel 8-12 $\mathrm{mm}\left(\mathrm{kg} / \mathrm{m}^{3}\right)$ & 847 & 615 & - \\
Fine Gravel 4-8 $\mathrm{mm}\left(\mathrm{kg} / \mathrm{m}^{3}\right)$ & 207 & 200 & 588 \\
Sand 0-4 mm $\left(\mathrm{kg} / \mathrm{m}^{3}\right)$ & 1134 & 818 & 1045 \\
Superplasticizer $\left(\mathrm{kg} / \mathrm{m}^{3}\right)$ & 5.5 & 5.5 & 5.7 \\
\hline
\end{tabular}

of the mortar samples until 300 days of testing in order to assess the long-term stability of the rebar. The corrosion current density $\left(i_{\text {corr }}\right)$ evolution was determined from $R_{P}$ measurements as $i_{\text {corr }}$ is inversely proportional to $\mathrm{R}_{\mathrm{P}}$, according to [1]:

$$
i_{c o r r}=\frac{B}{R_{P}}
$$

where

$\mathrm{i}_{\text {corr }}$ : corrosion current density $\left(\mu \mathrm{A} / \mathrm{cm}^{2}\right)$,

$\mathrm{R}_{\mathrm{P}}$ : polarization resistance $\left(\mathrm{k} \Omega \cdot \mathrm{cm}^{2}\right)$,

B: Tafel constant (a value of $26 \mathrm{mV}$ is usually used for this constant).

A three-electrode arrangement was used to carry out the $\mathrm{R}_{\mathrm{P}}$ measurements: the steel rebar was the working electrode, a graphite rod of $5 \mathrm{~mm}$ in diameter and $6 \mathrm{~mm}$ in length was used as counter-electrode and the saturated calomel electrode was used as reference electrode. The $R_{P}$ measurements were carried out by a linear sweep with a scan of $10 \mathrm{mV} / \mathrm{min}$ between $-20 \mathrm{mV}$ to $+20 \mathrm{mV}$ from the corrosion potential. The ohmic drop was compensated in each measurement to avoid the influence of the mortar resistance in the $\mathrm{R}_{\mathrm{P}}$ determination. The pore fluid $\mathrm{pH}$ of the fabricated mortars was also measured at different curing times following the method described by Alonso et al. (19).

\section{RESULTS AND DISCUSSION}

\subsection{Autogenous and drying shrinkage of low-pH cementitious materials}

Figure 1 shows the autogenous shrinkage of the fabricated mortars and Figure 2 the drying one after 28 days of curing in humidity chamber. Regarding the autogenous shrinkage, any remarkable difference was detected between the values measured in mortars without minerals additions and in the low-pH cases, even though the high mineral admixtures content of the latters. Therefore, the autogenous shrinkage of the evaluated low-pH cementitious materials was similar to the observed in the conventional mortars (OPC or CAC without mineral admixtures).

However, these results must be considered in their proper context. Although there are not many studies about the autogenous shrinkage of binders with the high mineral addition contents used in the low-pH cementitious materials (in fact, they are practically non-existent in the CAC case), higher autogenous shrinkage was expected in the low-pH mortars, mainly due to their high SF content $(20 \%$ in A-1 and $40 \%$ in B-1) (10). In the specific case of the low-pH mortars based on OPC, the C-S-H gels formed have low $\mathrm{C} / \mathrm{S}$ ratio and show larger specific surface area of water vapor (6); therefore, the pozzolanic reaction is expected to increase the specific surface area and thus enhances shrinkage (20). However, most of the published works are focused on high performance concretes so low w/c were used. Thus, the results obtained in the present paper could be explained considering the w/b ratio of the fabricated mortars (see Table 1). As previously mentioned, the w/b was chosen for the obtaining of an acceptable consistency for shotcreting as most of the applications evaluated in low-pH concretes for HLW repositories implied the use of the shotcrete technique. In this study, to ensure a similar consistency, the w/b ratios of the low-pH mortars were higher than the $w / b$ of the references, mainly due to the high silica fume content used as the addition of these high SF contents ( $>10-15 \%)$ promotes an increase in the water demand to obtain a similar consistency. In fact, their extreme particle thinness significantly increases the material specific surface in contact with water so more water is needed to complete hydration. On the contrary, FA increase the mix fluidity thus decreasing the water demand mainly due to their lower particle density (comparing to cement particles), and their so-called "ballbearing" effect (a consequence of their spherical shape) $(21,22)$. Therefore, the lower increase in the 

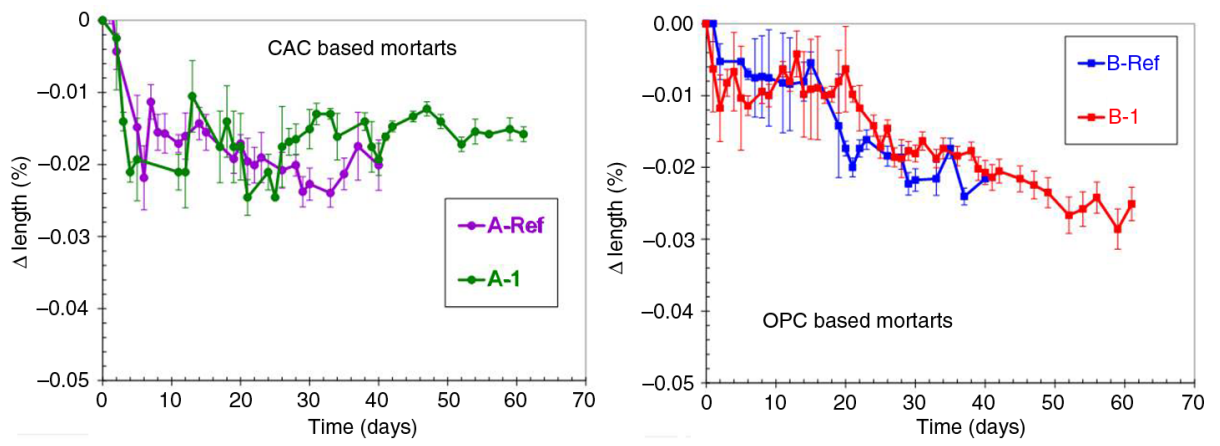

FIGURE 1. Autogenous shrinkage of the fabricated mortars.
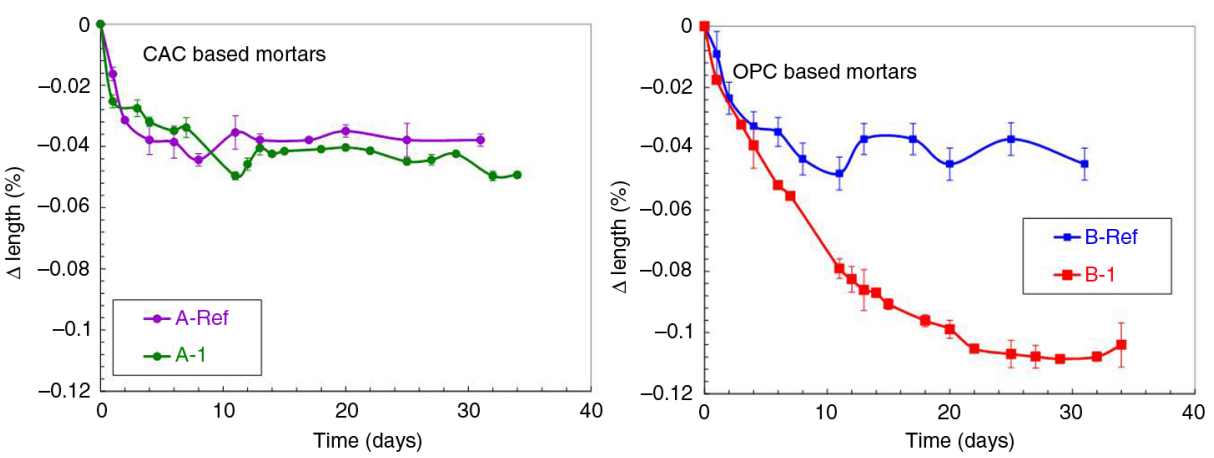

FiguRE 2. Drying shrinkage of the fabricated mortars.

w/b of A-1 with respect to A-Ref comparing to the increase obtained in the B-1 case is reasonable.

In this sense, the autogenous shrinkage increases with decreasing w/c ratio but also with increasing SF content (23). Therefore, in the evaluated materials the increase in the $\mathrm{w} / \mathrm{b}$ ratio generated in the low-pH mortars (mainly in B-1) should influence the autogenous shrinkage rather than the increase in the SF content. In fact, it has been published that, considering OPC based materials, the autogenous shrinkage is low when using $w / b>0.42$ but higher for $\mathrm{w} / \mathrm{b}$ ratios below this limit (24). Then, considering the material application (shotcrete) studied, the autogenous shrinkage of the evaluated low-pH cementitious materials was similar than the observed in conventional materials (OPC or CAC without mineral admixtures).

With respect to the drying shrinkage results, the values measured in the reference mortars were quite similar with stabilization after 7-10 days. Similar behavior was also observed in the A-1 mortar, possibly due to the presence of a $10 \%$ of FA in its composition as the presence of filler materials such as fly ash ultimately results in very significant reduction of total shrinkage (21). This also agrees with previous results of cementitious materials based on OPC plus FA (15). However, the drying shrinkage measured in the low-pH mortars based on OPC (B-1) is quite higher. In fact, the obtained final values demonstrated a high dimensional instability of the B-1 sample in drying conditions that exceeded the accepted limits. These results agree with the weight loss detected during the process, as shown in Figure 3 (the mortars where previously cured at $98 \% \mathrm{RH}$ with similar weight gain in all the cases) as the B-1 mortar suffered from the highest weight loss. The obtained

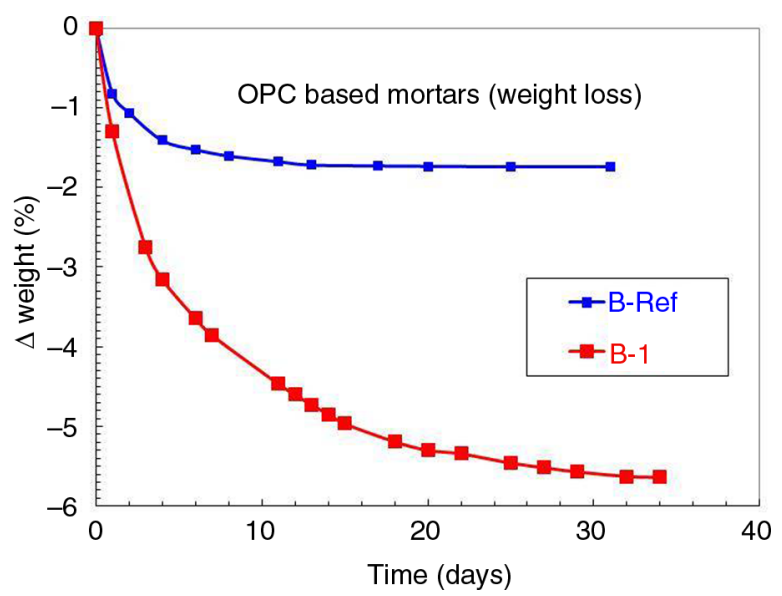

FIGURE 3. Weight loss of the low-pH mortars based on OPC in drying conditions. 

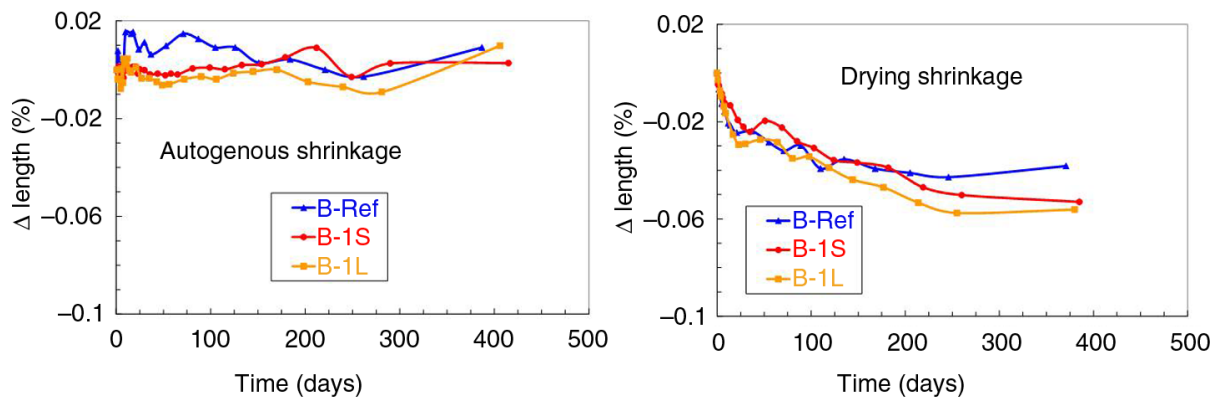

FIGURE 4. Autogenous and drying shrinkage of the fabricated concretes.

results also agree with others previously published in the literature where drying shrinkage increases were observed when the SF content also increases (for SF contents lower than $30 \%$ ) mainly due to pozzolanic reaction and pore size refinement mechanism promoted by silica fume. In fact, the main differences are detected in the short-term as the addition of SF has a dominating influence on the 28 days drying shrinkage (25). Higher drying shrinkage of low-pH mortars based on OPC but with binder composition different to B-1 was also detected in diverse environmental conditions (air and air-tightbag), possibly as a consequence of the porosity refinement generated in these low-pH materials (3).

Therefore, according to the obtained results the main shrinkage problems in low-pH cementitious materials are detected in the mortars based on OPC with high SF contents in drying conditions. For this reason, the same shrinkage tests were made using B-1 cement formulation (and B-Ref) but in concrete form as it will be the final material mainly used in HLW underground repositories. Moreover, as previously mentioned, the used concretes (see Table 2) were designed for the construction of a short (B-1S) and a long shotcrete plugs (B-1L) within the ESDRED project. In this case, the test lasted for a longer time in order to assess possible long-term modifications. Figure 4 shows the autogenous and the drying shrinkage measured in the evaluated concretes and Figure 5 the weight loss measured in drying conditions.

After almost 400 days of testing, the autogenous shrinkage of both low-pH concretes showed similar values than reference concretes and similar results that those obtained in mortars. The B-1S concrete showed the lowest autogenous shrinkage probably due to it also had the highest w/b ratio (see Table 2). With regard to the drying shrinkage, unlike the B-1 mortars, the inclusion of $40 \%$ of SF did not significantly increase the shrinkage measured although the final values were slightly higher in the low-pH concretes; the obtained results perfectly agree with the weight loss measured in each case (see Figure 5). This reduction of the drying shrinkage compared to that detected in the B-1 mortars can be due to the lower binder content of the B-1S and B-1L concretes. In fact, the values obtained clearly fulfill with the shrinkage limits defined elsewhere for supplementary cementitious material mixtures based on OPC (these percentage length change limits are 0.0400 at 28 days, and 0.0500 at 90 days) and they always comply with the accepted total limit of $0.1 \%$; should shrinkage exceeds this limit, cracks in the concrete (8).

Regarding the obtained results, Whiting et al. (26) found that the tendency of concrete with SF to crack due to shrinkage is mainly influenced by the curing of the concrete not the addition of SF. When the concrete is cured for 7 days in a continually moist condition, there was no statistically significant effect on the tendency of the concrete to crack. In this sense, the concretes fabricated in the present study were accordingly cured during 28 days before being subjected to drying conditions. Moreover, Alsayed (27) defined that for specimens cured under controlled laboratory conditions, inclusion of SF (although in proportions lower than that used in this study, 10\%) in the concrete mix reduced the 3-year drying shrinkage by $25 \%$, so long-term problems related with this issue are not expected in low-pH concretes based on OPC plus SF.

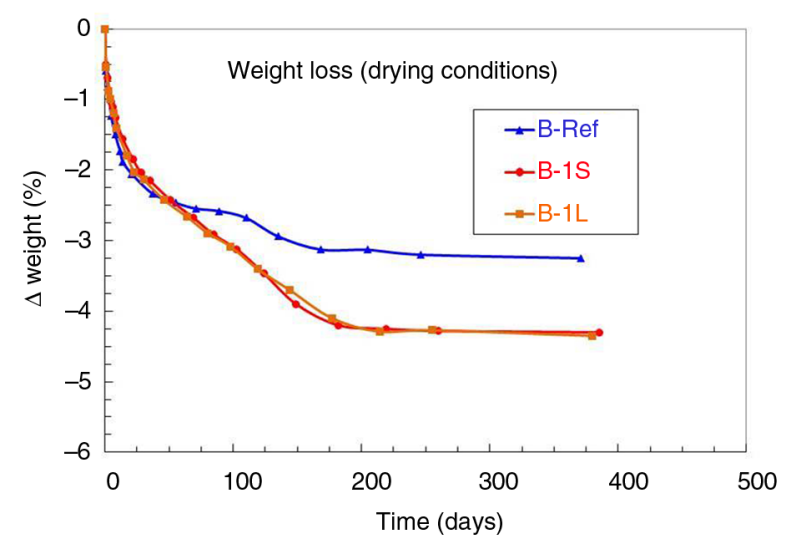

Figure 5. Weight loss of the fabricated concretes in drying conditions. 
Therefore, in the final materials designed (low-pH concretes for shotcrete plug construction) the high mineral admixtures contents existing in the low-pH binders based on OPC do not generate a significant increase in the shrinkage phenomena (autogenous or drying). When using CAC, even in mortars the differences detected between the low-pH materials and the conventional ones are negligible. This clearly favors the use of low $\mathrm{pH}$ concretes based on OPC or CAC in HLW underground repositories. However, it should be noted that the fabricated low-pH cementitious materials of this study were designed considering the shotcreting application that implied the use of a high $\mathrm{w} / \mathrm{b}$ ratio.

\subsection{Effect of the use of low-pH binders based on OPC in the corrosion performance of reinforcement}

As defined in the introduction, the disposal of HLW in underground repositories often could require the use of reinforced concrete for structural support; in previous work the initiation of an active corrosion process was detected when using carbon steel reinforcement in low-pH mortars (18). According to these results, galvanized steels were also taken into account in present paper. Figure 6 shows the corrosion current density evolution $\left(\mathrm{i}_{\text {corr }}\right)$ for both carbon $(\mathrm{C})$ and galvanized steel $(\mathrm{G})$ reinforcement embedded in both mortar mixes (B-Ref and B-1). The mean value of four samples is represented, as similar evolution was observed in each case. For comparison purposes, Figure 7 shows the pore solution $\mathrm{pH}$ evolution measured in both types of mortars. Initially, after few days in contact with the mortars, both types of reinforcement reached low corrosion rate values $\left(<0.1 \mu \mathrm{A} / \mathrm{cm}^{2}\right)$ regardless of the mortar type, identified as passive state in all cases. However, in the case of low pH mortars with carbon steel reinforcement, the corrosion was initiated after 30 days, when the pore solution $\mathrm{pH}$ had also decreased to values below 11.5, and values even up to $1 \mu \mathrm{m} / \mathrm{cm}^{2}$ were reached followed by decreases till $\mathrm{i}_{\text {corr }}<0.1 \mu \mathrm{A} / \mathrm{cm}^{2}$ associated to metastable processes of corrosion onset and repasivation (Figure 6). A local depasivation with the formation of tiny pits was observed at the end of the test when the steel bars were removed from the mortar but, as expected from the electrochemical measurements, this was not observed in B-Ref due to its high alkaline pore solution. When using galvanized reinforcement, corrosion problems were not detected in any case, as they remained below the passive limit of $i_{\text {corr }}$ once the passive layer is formed and they were not altered by the pore fluid $\mathrm{pH}$ changes recorded.

These differences in corrosion performance between carbon steel and galvanized steel with respect to the alkalinity of the mortars are more clearly observed in Figure 8, in which data of cumulated corrosion have been represented. This type of representation has been recently proposed as interesting tool to evaluate the corrosion behavior of rebar embedded in cementitious materials (28), as the slope of the curve can be related to the representative corrosion rate (29). The dotted lines delimit the theoretical

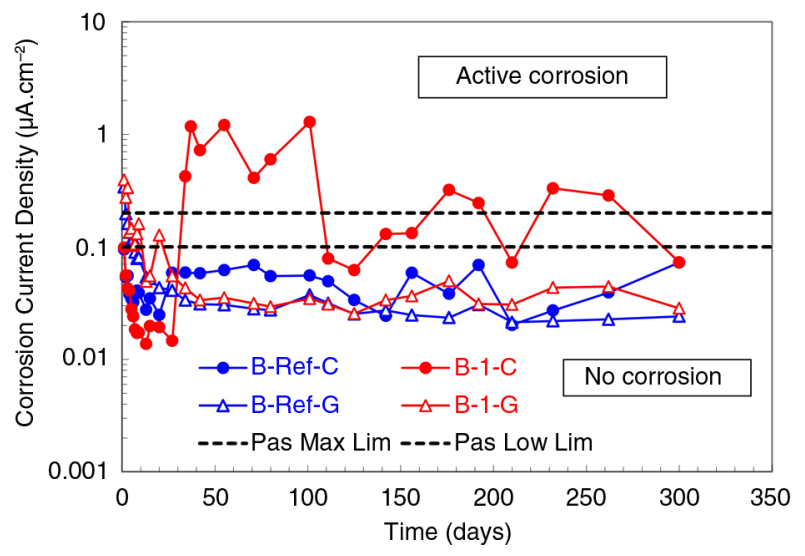

FiguRE 6. Corrosion current density evolution (C: carbon steel; G: galvanized steel).

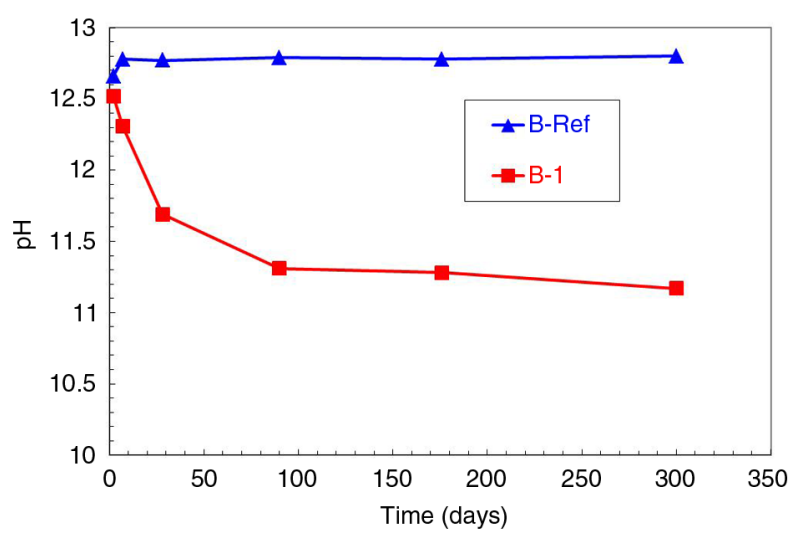

FIGURE 7. Pore solution $\mathrm{pH}$ evolution of the mortars based on OPC.

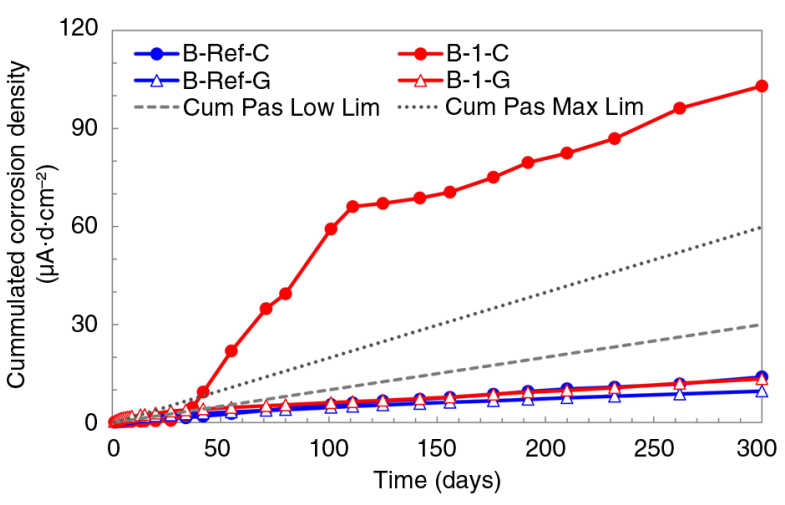

Figure 8. Cumulated Corrosion Density (C: carbon steel; G: galvanized steel). 


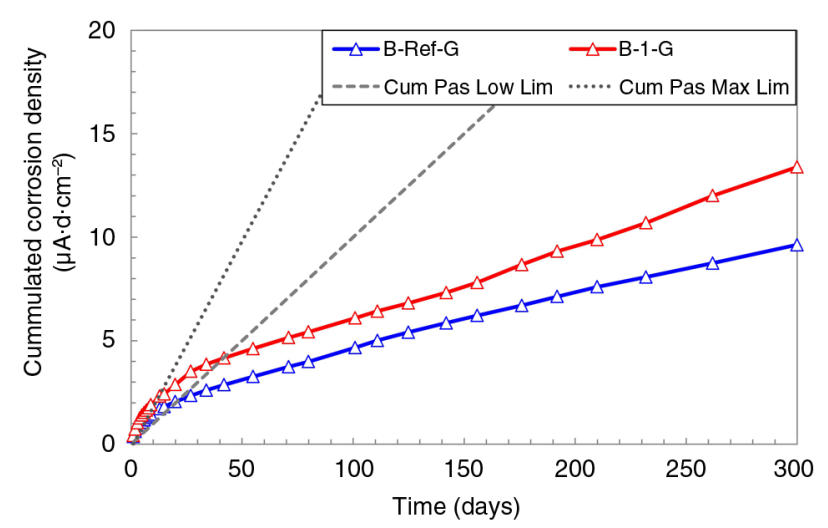

Figure 9. Cumulated Corrosion Density for the specific case of galvanized rebar $(\mathrm{G})$.

limit between active $\left(\mathrm{i}_{\text {corr }}=0.2 \mu \mathrm{A} / \mathrm{cm}^{2}\right)$ and passive states $\left(i_{\text {corr }}=0.1 \mu \mathrm{A} / \mathrm{cm}^{2}\right)$. Only carbon steel rebar embedded in the low-pH mortars exceeded the limit of cumulated corrosion corresponding to the theoretical limit of corrosion onset when the $\mathrm{pH}$ decreased below 11.5 (see also Figure 7). A sharp change of the slope is registered, indicating that the characteristic passive layer formed in alkaline media on carbon steel rebar was not stable anymore and the corrosion onset occurred at this pore solution $\mathrm{pH}$ value. A representative corrosion rate of $0.83 \mu \mathrm{A} / \mathrm{cm}^{-2}$ is estimated from the slope in the period of time from 40-100 days that clearly corresponds to ongoing active corrosion processes. Although the corrosion evolved slowly after 100 days of exposure, the slope estimated in this region indicates a representative corrosion rate of $0.21 \mu \mathrm{A} / \mathrm{cm}^{-2}$, just in the limit established as maximum for corrosion onset. In the case of the steel rebar embedded in the B-Ref mortar, the representative corrosion rate estimated from the slope of the curve, $0.048 \mu \mathrm{A} / \mathrm{cm}^{2}$, indicates a clear situation of passivity; in this case, once the passive layer is formed it continues stable provided the high alkaline environment remains in OPC (30).

For a better understanding of the corrosion processes registered during the exposure of galvanized reinforcement, in Figure 9 the Cumulated Corrosion Density evolution of galvanized bars in both types of mortar is included. During the first days of exposure to the alkaline media, high values of cumulated corrosion are detected (even above the corrosion onset limit) until the passive state is reached and a protective layer of calcium hydroxizincate $(\mathrm{CHZ})$ is formed on the surface of the reinforcement (31). The type of mortar seems to influence the passivation time as it is faster for the rebar embedded in B-Ref mortars. However, after the formation of the passive layer of hydroxizincate, a representative corrosion rate clearly below the $0.1 \mu \mathrm{A} / \mathrm{cm}^{2}$ established as lower limit for passivity, has been estimated from the slope of the obtained curves $\left(0.026 \mu \mathrm{A} / \mathrm{cm}^{2}\right.$ for B-Ref and $0.035 \mu \mathrm{A} / \mathrm{cm}^{2}$ for B-1).

\section{CONCLUSIONS}

Regarding the shrinkage tests, the obtained results show that the autogenous shrinkage of low-pH cementitious materials shows similar values than the reference samples. With respect to the drying shrinkage, the main problems in low-pH cementitious materials are related with the mortars based on OPC with high SF contents. However, the drying shrinkage of the low-pH concretes based on OPC (designed for the construction of the plugs), is similar than that measured in the reference OPC concrete of equivalent consistency, probably due to the low binder content of these special concretes.

Considering the use of reinforced concretes in HLW repositories, the low-pH cements do not guaranty stability for carbon steel. Therefore, a protection measure is needed. In fact, the stability of galvanized reinforcement in pore fluid $\mathrm{pH}$ values below 11 has been confirmed in present paper.

\section{ACKNOWLEDGMENTS}

Authors are grateful to EU Project ESDRED (FI6W-CT-2004-508851) and ENRESA for their support for this work. Authors also acknowledge to the Spanish Ministry of Economy and Competiveness for the economic support through project BIA 2011_22760. They are also grateful to "Cementos Portland Valderribas" and "Ciments Molins S.A." for supply some of the raw materials used in this study. M. Sánchez also acknowledges her Juan de la Cierva Postdoctoral position (JCI-2011-09572).

\section{REFERENCES}

1. Gray, M.N.; Shenton, B.S. (1998) For better concrete, take out some of the cement. In: Proc. 6th ACI/CANMET Symposium on the Durability of Concrete, Bangkok, Thailand.

2. Iriya, K.; Matsui, A.; Mihara, M. (1999) Study on applicability of HFSC for radioactive waste repositories. In: Radioactive Waste Management and Environmental Remediation, ASME Conference, Nagoya, Japan, 16-30.

3. Cau Dit Coumes, C.; Courtois, S.; Nectoux, D.; Leclerq, S.; Bourbon, X. (2006) Formulating a low-alkalinity, highresistance and low-heat concrete for radioactive waste repositories. Cem. Concr. Res. 36, 2152-2163. http://dx.doi. org/10.1016/j.cemconres.2006.10.005.

4. Yamamoto, T.; Imoto, H.; Ueda, H.; Hironaga, M. (2007) Leaching alteration of cementitious materials and release of organic additives. In: Proc. R\&D on Low-pH Cement for a Geological Repository, 3rd Workshop, June 13-14 Paris, France, 52-62.

5. Codina, M.; Cau-dit-Coumes, C.; Le Bescop, P.; Verdier, J.; Ollivier, J.P. (2008) Design and characterization of low-heat and low-alkalinity cements. Cem. Concr. Res. 38, 437-448. http://dx.doi.org/10.1016/j.cemconres.2007.12.002.

6. García Calvo, J.L.; Hidalgo, A.; Alonso, C.; Fernández Luco, L. (2010) Development of low-pH cementitious materials for HLRW repositories. Resistance against ground waters aggression. Cem. Concr. Res. 40, 1290-1297. http:// dx.doi.org/10.1016/j.cemconres.2009.11.008. 
7. García Calvo, J.L.; Alonso, M.C.; Hidalgo, A.; Fernández Luco, L.; Flor-Laguna, V. (2013) Development of low-pH cementitious materials based on CAC for HLW repositories: Long-term hydration and resistance against groundwater aggression. Cem. Concr. Res. 51, 67-77. http://dx.doi.org/10. 1016/j.cemconres.2013.04.008.

8. Mokarem, D.W. (2002) Development of concrete shrinkage performance specifications. Thesis (PhD). Faculty of the Virginia Polytechnic Institute and State University.

9. Ossa, M.; David, J. (1992) The effect of pozzolan additions on the shrinkage of cement pastes and mortars during their first hours of age. Mater. Construcc. 42 [225], 37-63. http:// dx.doi.org/10.3989/mc.1992.v42.i225.720.

10. Wiegrink, K.; Marikunte, S.; Shah, S.P. (1996) Shrinkage Cracking of High Strength Concrete. ACI Materials Journal, 93, 409-415.

11. Tazawa, E.; Yonekura, A. (1986) Drying shrinkage and creep of concrete with condensed silica fume. In: Proceedings of the 2nd International Conference on Fly Ash, Silica Fume, Slag and Natural Pozzolans in Concrete, Madrid, Spain, ACI Publication SP A1, 903-921.

12. Haque, M.N. (1996) Strength Development and Drying Shrinkage of High Strength Concretes. Cem. Concr. Comp. 18, 333-342. http://dx.doi.org/10.1016/0958-9465(96)00024-8

13. Tangtermsirikul, S.; Sudsangium, T.; Nimityongsakul, P. (1995) Class C Fly Ash as a Shrinkage Reducer for Cement Paste. In: Proceedings of the 5th CANMET/ACI International Conference on Fly Ash, Silica Fume, Slag and Natural Pozzolans in Concrete, Milwaukee, Wisconsin, USA, 1, 385-401.

14. Zhou, M.Z.; Slater, J.R.; Wavell S.E.; Oladiran, O. (2012) Effects of PFA and GGBS on early-ages engineering properties of Portland cement systems. J. Adv. Concr. Tech. 10, 74-85. http://dx.doi.org/10.3151/jact.10.74

15. Gebler, S. H.; Klieger P. (1986) Effect of Fly Ash on Physical Properties of Concrete, RD089, Portland Cement Association, Skokie, IL.

16. Ugur, K.N.; Turker, F. (2007) Effect of environmental conditions on the properties of concretes with different cement types. Constr. Build. Mat. 21, 634-645. http://dx.doi.org/ 10.1016/j.conbuildmat.2005.12.004.

17. Persson, B. (1998) Experimental studies on shrinkage of high-performance concrete. Cem. Concr. Res. 28, 1023-36. http://dx.doi.org/10.1016/S0008-8846(98)00068-4.

18. García Calvo, J.L.; Sánchez, M.; Alonso, M.C.; Hidalgo, A.; García, J. (2013) Study of the microstructure evolution of low-pH cements based on Ordinary Portland Cement (OPC) by Mid- and Near-Infrared spectroscopy, and their influence on corrosion of steel reinforcement. Materials. 6, 2508-2521. http://dx.doi.org/10.3390/ma6062508.

19. Alonso, M.C.; García Calvo, J.L.; Walker, C.; Naito, M.; Pettersson, S.; Puigdomenech, I.; Cuñado, M.A.; Vuorio, M.; Weber, H.; Ueda, H.; Fujisaki, K. (2012) Development of an accurate $\mathrm{pH}$ measurement methodology for the pore fluids of low $\mathrm{pH}$ cementitious materials. SKB R-12-02. Stockholm, SKB. Svensk Kärnbränslehantering AB. Swedish Nuclear Fuel and Waste Management.

20. Kantro, D.L.; Brunauer, S.; Weise, C.H. (1962) Development of surface in the hydration of calcium silicates II. Extention of investigations to earlier and later stages of hydration. J. Phys. Chem. 66, 1804-1809. http://dx.doi.org/10.1021/ j100816a007.

21. Lee, S.H; Kim, H.J ; Sakai, E; Daimon, M. (2003) Effect of particle size distribution of fly ash-cement system on the fluidity of cement pastes. Cem. Concr. Res. 33, 763-768. http://dx.doi.org/10.1016/S0008-8846(02)01054-2.

22. Megat Johari, M.A.; Brooks, J.J.; Kabir, S.; Rivard, P. (2011) Influence of supplementary cementitious materials on engineering properties of high strength concrete. Constr. Build. Mat. 25, 2639-2648. http://dx.doi.org/10.1016/j. conbuildmat.2010.12.013.

23. Zhang, M.H.; Tam, C.T.; Leow, M.P. (2003) Effect of waterto-cementitious materials ratio and silica fume on the autogenous shrinkage of concrete. Cem. Concr. Res. 33, 1687-1694. http://dx.doi.org/10.1016/s0008-8846(03)00149-2.

24. Aitcin, P.C. (2003) The durability characteristics of high performance concrete: a review. Cem. Concr. Comp. 25, 409-20. http://dx.doi.org/10.1016/S0958-9465(02)00081-1.

25. Appa Rao, G. (2001) Long-term drying shrinkage of mortar-influence of silica fume and size of fine aggregate. Cem. Concr. Res. 31, 171-175. http://dx.doi.org/10.1016/ S0008-8846(00)00347-1.

26. Whiting, D.A.; Detwler, R.J.; Lagergren, E.S. (2000) Cracking tendency and drying shrinkage of silica fume concrete for bridge deck applications. ACI Materials Journal. 97, 71-77.

27. Alsayed, S.H. (1998) Influence of superplasticizer, plasticizer, and silica fume on the drying shrinkage of highstrength concrete subjected to hot-dry field conditions. Cem. Concr. Res. 28, 1045-1415. http://dx.doi.org/10.1016/ S0008-8846(98)00102-1.

28. Castro-Borges, P.; Balancán-Zapata, M.; López-González, A. (2013) Analysis of Tools to Evaluate Chloride Threshold for Corrosion Onset of Reinforced Concrete in Tropical Marine Environment of Yucatán, México. J. Chem. 1. http:// dx.doi.org/10.1155/2013/208619.

29. Andrade, C.; Rebolledo, N.; Pedrosa, F. (2012) From the instantaneous corrosion rate to a representative value. In: Concrete Repair, Rehabilitation and Retrofitting III Alexander et al. (eds), London, 59-63.

30. Sánchez, M.; Gregorio, J.; Alonso, C.; García-Jareño, J.J.; Takenouti, H.; Vicente, F. (2007) Electrochemical impedance spectroscopy for studying passive layers on steel rebars immersed in alkaline solutions simulating concrete pores. Electrochim. Acta. 52, 7634-7641. http://dx.doi.org/10.1016/j. electacta.2007.02.012.

31. Andrade, C.; Alonso, C. (2003) Electrochemical aspects of galvanized reinforcement corrosion. In: S.R. Yeomans, Galvanized steel reinforcement in concrete. Elsevier, 111-144. 